\title{
Determinants of Export Competitiveness: An Empirical Study of Tea Industry in Sri Lanka
}

by

Konara Mudiyanselage Vilani Sachitra

(Registration Number: 5266 FM2011 1039) 


\section{Determinants of Export Competitiveness: \\ An Empirical Study of Tea Industry in Sri Lanka}

by

Konara Mudiyanselage Vilani Sachitra

(Registration Number: 5266FM2011039)

A thesis submitted to the University of Sri Jayewardenepura in partial fulfillment of the requirements for the Degree of Master of Science in Management on 31 $1^{\text {st }}$ January 2013. 


\section{Declaration of Student}

The work described in this thesis was carried out by me under the supervision of Dr. P.J. Kumarasinghe and a report on this has not been submitted in whole or in part to any university or any other institute for another degree/diploma.

K.M.Vilani Sachitra

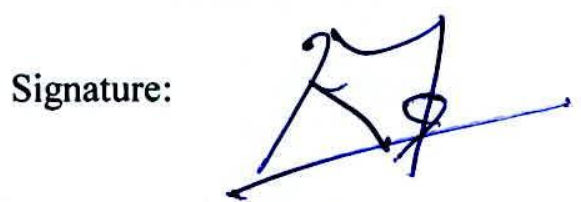

Date: $\quad 17 / 06 / 2014$ 


\section{Declaration of Supervisor}

I certify that the above statement made by the candidate is true and that this thesis is suitable for submission to the university for the purpose of evaluation.

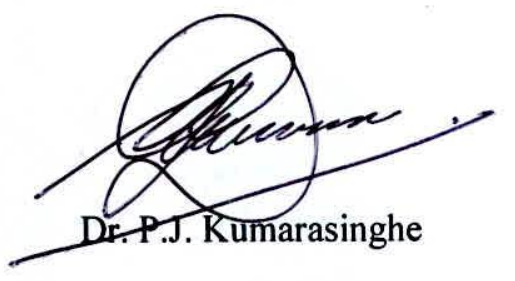

Signature:

Date: 
Table of Content

Lists of Tables

Lists of Figures

Acknowledgment

Abstract

$\begin{array}{ll}\text { 1. Introduction } & 01\end{array}$

1.1 Competitiveness Index and Sri Lanka 03

1.2 Tea Industry 06

$\begin{array}{lll}1.3 & \text { Problem Statement of the study } & 15\end{array}$

$\begin{array}{lll}1.4 & \text { Objectives of the Study } & 16\end{array}$

$\begin{array}{lll}1.5 & \text { Significance of the Study } & 16\end{array}$

$\begin{array}{lll}1.6 & \text { Scope of the Study } & 17\end{array}$

$\begin{array}{ll}1.7 & \text { Limitations of the Study } \\ \end{array}$

$\begin{array}{lll}1.8 & \text { Structure of the study } & 19\end{array}$

$\begin{array}{lll}1.9 & \text { Summary } & 19\end{array}$

2. Literature Review 20

2.1 Overview of Sri Lankan Economy 20

2.2 International Trade Theories 23

2.3 Competitiveness 26

2.4 Export Competitiveness 31

2.5 Porter's Diamond Model 40

2.6 Limitations of Porter's Diamond model 48

2.7 Competitiveness Measurements 49

$\begin{array}{lll}2.8 & \text { Brand Loyalty } & 61\end{array}$

$\begin{array}{lll}2.9 & \text { Summary } & 69\end{array}$

$\begin{array}{lr}\text { 3. Methodology } & \mathbf{7 0}\end{array}$

$\begin{array}{lll}3.1 & \text { Research Approach } & 70\end{array}$

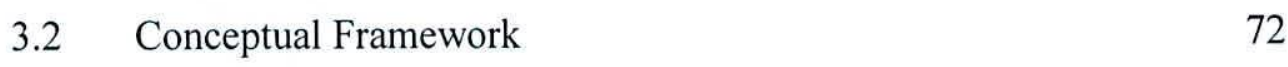

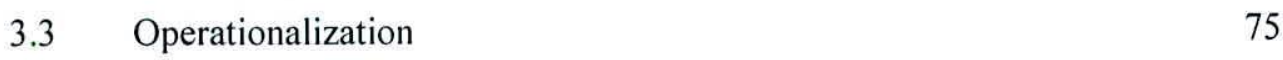


$\begin{array}{lll}3.4 & \text { Population and Sample } & 81\end{array}$

3.5 Data Collection $\quad 82$

$\begin{array}{lll}3.6 & \text { Statistical Method } & 84\end{array}$

3.7 Hypotheses Development $\quad 88$

$\begin{array}{lll}3.8 & \text { Summary } & 90\end{array}$

4. Data Analysis and Findings 91

4.1 Overview of Pilot Survey Results 91

4.2 Data Analysis of the Study 95

4.3 Validation of Measurement Properties 98

$\begin{array}{lll}4.4 & \text { Path Coefficient } & 105\end{array}$

$\begin{array}{lll}4.5 & \text { Bootstrapping } & 108\end{array}$

4.6 Findings of the Study 112

$\begin{array}{lll}4.7 & \text { Summary } & 120\end{array}$

$\begin{array}{ll}\text { 5. Discussion } & 122\end{array}$

5.1 Overview of the Findings of the Study 122

5.2 Assessment of Literature Review and Findings of the Study 123

5.3 Managerial Implications 134

5.4 Further Research Insight 138

$\begin{array}{lll}5.5 & \text { Summary } & 138\end{array}$

6. Summary and Conclusion 139

$\begin{array}{ll}\text { 7. } & \mathbf{1 4 2}\end{array}$

8. Annexure

Annexure 01 - Questionnaire 163

Annexure 02 - Pilot Survey Results 169 


\section{List of Tables}

$\begin{array}{lll}\text { Table 1.1 Export volume and share of selected countries } & 03\end{array}$

Table 1.2 Global Competitiveness Index of selected countries 04

$\begin{array}{lll}\text { Table } 1.3 & \text { Reasons to drink tea } & 07\end{array}$

Table 1.4 Area of tea planted (Elevation wise) 09

Table 1.5 Tea Production (Elevation wise) of Sri Lanka 09

Table 1.6 Tea Production (Category wise) of Sri Lanka 10

$\begin{array}{lll}\text { Table } 1.7 & \text { Sri Lanka Tea Export (Quantity) } & 11\end{array}$

$\begin{array}{lll}\text { Table 1.8 } & \text { Market share of the major tea exporting countries }\end{array}$

$\begin{array}{lll}\text { Table 1.9 Major tea exporting countries of Sri Lanka } & 12\end{array}$

$\begin{array}{lll}\text { Table 1.10 } & \text { Major tea exporting countries of Kenya } & 14\end{array}$

Table 2.1 Composition of exports in Sri Lanka 22

Table 2.2 Indicators of Competitiveness

$\begin{array}{lll}\text { Table } 3.1 & \text { Operationalization of the variables } & 78\end{array}$

$\begin{array}{lll}\text { Table 4.1 Type of organization } & 96\end{array}$

Table 4.2 Years of tea exporting experience 96

Table 4.3 Number of workers engaged in the firm 96

$\begin{array}{lll}\text { Table } 4.4 & \text { Export revenue in } 2012 & 97\end{array}$

Table 4.5 Outer loading (Factor loading) 98

$\begin{array}{lll}\text { Table 4.6 Composite Reliability } & 100\end{array}$

$\begin{array}{lll}\text { Table } 4.7 & \text { Latent Variable Correlation } & 101\end{array}$

$\begin{array}{lll}\text { Table } 4.8 \text { Cross Loading } & 102\end{array}$

Table 4.9 Multicollinearity Statistics in Regression Model 104

$\begin{array}{lll}\text { Table 4.10 Path Coefficient } & 105\end{array}$ 
$\begin{array}{lll}\text { Table } 4.11 & \text { Outer Weights } & 107\end{array}$

Table 4.12 Outer Weights Mean, Standard Deviation and T-Value 109

Table 4.13 Outer Loading Mean, Standard Deviation and T-Value 110

$\begin{array}{ll}\text { Table 4.14 Significance of Path Coefficient } & 111\end{array}$

Table 4.15 The effect of the factor conditions on the tea export competitiveness

Table 4.16 The effect of the demand conditions on the tea export competitiveness

Table 4.17 The effect of the related and supporting industries on the tea export competitiveness

Table 4.18 The effect of the government support on the tea export competitiveness

Table 4.19: The effect of the brand loyalty on the tea export competitiveness 116 


\section{List of Figures}

Figure 1.1 Tea Growing Regions of Sri Lanka

Figure 1.2 Reveal Comparative Advantage of Tea in major tea export countries

Figure 2.1 Model of measurement of the national export competitiveness 35

Figure 2.2 Sri Lankan Tea Industry: competitiveness diamond 46

Figure 2.3 Conceptual model of brand loyalty 68

Figure 3.1 Research Model Sun et al., (2010) 73

Figure 3.2 Research model of Bakan and Dogan (2012) 73

Figure 3.3 Conceptual Framework of the Study 74

Figure 4.1 PLS-SEM Algorithm 99

Figure 4.2 Bootstrapping 108

Figure 4.3 Proposed Model of the Study 


\section{ACKNOWLEDGMENT}

I would like to acknowledge the efforts of different individuals who made numerous contributions towards the completion of this work. First and foremost I would like to extend my sincere appreciation to my supervisors Dr. P.J. Kumarasinghe, for his invaluable time, guidance and encouragement that enabled me to complete this research in time.

Special appreciation goes to the Faculty of Management Studies and Commerce especially the Dean: Professor. Sampath Amarathunge and Head of Department Professor. E. Dayarathne for the facilitation and encouragement they rendered to me during my studies. And also I would like to thank, Ms. Nalini Colombage, Deputy Director, IT Division, Export Development Board, and tea exporters who responded my questionnaire, for encouragement and information support.

Respondents are the key players who cooperate much to success primary data collected survey. Then special appreciation goes to all the respondents for spending their valuable time to complete the questionnaire of the study. To my parents thank you for your love and immeasurable moral support. To my friends and to the entire MBA/MSc.-2011 group for your company and intellectual contributions. 


\title{
Determinants of Export Competitiveness: An Empirical Study of Tea Industry in Sri Lanka
}

\author{
Konara Mudiyanselage Vilani Sachitra
}

\begin{abstract}
Export development plays an important role in promoting economic growth and development. Understanding of export competitiveness has primarily been pursued in terms of economic variables and market conditions. The thesis involved an investigation into the determinants of export competitiveness of tea industry in Sri Lanka. The main purpose of this study is to identify the factors which affecting to the competitiveness of tea industry in Sri Lanka and to develop a framework that helps to enhance the competitiveness of tea industry. This study integrated perspectives from export competitiveness, the resource based view of the firm, local and foreign demand conditions of the firm, association with related and supporting industries, government sources and brand loyalty. Quantitative research approach was used and Porter's diamond model with some adaptations was taken as proposed model of this study. Email survey compromised with the structured questionnaire was used to collect primary data from the sample. Key managers of tea exporting firms were considered as the respondents. Partial least squares structural equation model (PLS-SEM) was utilized to analyze the contribution of each factor on tea export competitiveness. The data obtained from the firm level survey were analyzed using Smart PLS version 2.0 and SPSS (version 16) statistical packages. Supported by the empirical evidences this study found out that factor conditions have the most significant influence of export competitiveness
\end{abstract}


of tea industry and the second important is government support. Followed by government support, demand condition and brand loyalty have also made positive impact on export competitiveness of tea industry in Sri Lanka. Then the results suggested that factor conditions, demand conditions, government support, brand loyalty and related and supporting industries can help Sri Lankan tea industry to sustain its competitive advantage. While identifying important elements, results indicated that raw material, technology, physical infrastructure, information infrastructure, related industries, and firm characteristics have significant impact. Giving priority to those elements strategies should be developed to enhance competitiveness of Sri Lankan tea export. By creating favourable conditions, Sri Lanka can remain competitive in the global tea market. Furthermore, it is more vital to conduct a comparative analysis of determinants of export competitiveness and to assess the interaction among the factors affecting to export competitiveness.

Key words: Tea industry, Competitiveness, Porter's diamond model, Partial least squares structural equation model 


\section{INTRODUCTION}

The process of economic integration, globalization and technological advancement strengthen export development of nations. Export development plays an important role in promoting economic growth and development. It contributes significantly to enhance capital inflow, reduce trade balance deficits, make balance of payment (BOP) surplus, increase employment and expand the production base of a nation. As a result of increasing size of international trade, the concept of export competitiveness plays a vital role in international trading system. Export competitiveness has been paid more attention in order to develop export portfolio of nations. To promote economic development and survival in the global competitive market, export competitiveness is an essential component of a country.

The nation's long-term survival depends on how it compares with other countries which produce similar products. For small economies, export is substantial in sustaining growth and vitality (Saboniene, 2009, p.49). Export contributes economy in terms of capital inflows, employment, expansion of industry widening the production base, and achieve economies of scale in domestic industries.

Sri Lanka's national economy has expanded during the post independent period. In 1950 Sri Lanka recorded US $\$ 1$ billion gross domestic product and it has expanded to US $\$ 60$ billion in 2012. Throughout this expansion, service sector provides mass contribution to national economy. The expansion of domestic production does not contribute much on the external sector (depends on domestic market); it can be examined by referring declining share of Sri Lanka's export on GDP and world trade. The share of Sri Lanka's 
export as a percentage of gross domestic products (GDP) is fluctuating from time to time, however, after 2005 it shows a continuous declining tendency. Considering the time period; in 1950, share of export of GDP was 28 percent, 1970 it was 20 percent, in 2000 it was 33 percent, 2005, 26 percent, 2007, 24 percent, 2009, 17 percent, 2010, 18 percent, 2011, 18 percent and last recorded in 2012 it was 16.67 percent (Central Bank Reports). There is no significant expansion of foreigners' demand for Sri Lanka's products. Since 2005, economic growth has recorded above 6 percent and last two years (2010 and 2011) it reached to 8 percent. Declining tendency of export share of GDP indicates that Sri Lanka was unable to raise its export at least at the same rate as GDP growth. Depending on domestic market is not a good development signal for a country like Sri Lanka because it does not have a strong domestic market compared to India and China.

World export value has doubled during the time period from 2000 to 2011, but Sri Lanka's export value increased relatively little amount compared to other Asia countries like India, Bangladesh, Thailand, Vietnam and Philippine. For an example; India, Bangladesh, Indonesia, Philippines, and Vietnam increased their export market share in 2011, compared with 2010 export market share, by 17, 15, 10, 9, and 18 percent respectively. Sri Lanka's share in the world total export has declined drastically from year 2000 to 2011 (Table 1.1). Based on the International Trade Center (ITC) statistical data, Sri Lanka's share in world export; $2000-0.08$ percent, $2005-0.06$ percent, 2009 0.05 percent, $2010-0.048$ percent $2011-0.04$ percent and $2012-0.055$ percent. 
Table 1.1: Export volume and share of selected countries

\begin{tabular}{lccccc}
\hline \multirow{2}{*}{ Country } & \multicolumn{3}{c}{ Export Volume (US \$) } & \multicolumn{3}{c}{$\begin{array}{c}\text { Export as a percentage } \\
\text { of world export }\end{array}$} \\
& $\mathbf{2 0 0 1}$ & $\mathbf{2 0 1 0}$ & $\mathbf{2 0 1 1}$ & $\mathbf{2 0 1 0}$ & $\mathbf{2 0 1 1}$ \\
\hline Thailand & $64,919,226$ & $195,311,520$ & $228,823,973$ & 1.26 & 1.26 \\
Philippines & $31,150,203$ & $38,435,802$ & $51,497,515$ & 0.33 & 0.36 \\
Sri Lanka & $\mathbf{4 , 6 7 2 , 0 0 1}$ & $\mathbf{8 , 3 0 4 , 0 5 2}$ & $\mathbf{1 0 , 0 1 0 , 8 1 8}$ & $\mathbf{0 . 0 4 8}$ & $\mathbf{0 . 0 4}$ \\
Vietnam & $15,029,192$ & $72,236,665$ & $97,730,073$ & 0.46 & 0.54 \\
India & $43,878,489$ & $220,408,496$ & $301,483,250$ & 1.42 & 1.66 \\
Bangladesh & $5,417,273$ & $19,955,832$ & $25,891,270$ & 0.13 & 0.15 \\
Singapore & $121,753,789$ & $351,867,167$ & $409,503,631$ & 2.25 & 2.25 \\
Indonesia & $56,316,867$ & $157,779,103$ & $203,496,619$ & 1.01 & 1.12 \\
\hline
\end{tabular}

Source: International Trade Center (ITC) database

Sri Lanka being a tiny economy has an insignificant share of exports in the world exports. It is even less than $1 \%$. Thus, its share in world exports amounted to about $0.085 \%$ in 2000 and that share had declined to about $0.055 \%$ in 2012 . It depicts that when the world exports have been rising, Sri Lanka has failed to keep pace with the global growth trends. It demonstrates the existence of a serious structural problem relating to Sri Lanka's export sector and immediate measures must be applied to correct those structural issues.

\subsection{Competitiveness Index and Sri Lanka}

The Atlas of Economic Complexity Index (ECI) assesses the complexity of each product produced by a nation. The ECI measures ubiquity (number of countries that a product is connected to) and diversity (number of products that a country is connected to) of a particular product. The ECI shows a clear picture on competitiveness of a country's product. In the ECI (2011), Sri Lanka's ranking in the index is No.71. While comparing 